\title{
Youth Sports Activities on Emotional Intelligence
}

\author{
$1^{\text {st }}$ Pulung Riyanto* \\ Department of Physical Education, \\ Health, and Recreation \\ Universitas Musamus \\ Merauke, Indonesia \\ riyanto_fkip@unmus.ac.id
}

\author{
$2^{\text {st }}$ Syamsudin \\ Department of Physical Education, \\ Health, and Recreation \\ Universitas Musamus \\ Merauke, Indonesia \\ syamsudin@unmus.ac.id
}

\author{
$2^{\text {st }}$ Pande Made Dharma Sanjaya \\ Department of Physical Education, \\ Health, and Recreation \\ Universitas Musamus \\ Merauke, Indonesia \\ sanjaya_fkip@unmus.ac.id
}

\begin{abstract}
This study aims to determine the effect sports activity in increasing emotional intelligence. The research method used is an experimental method. the results of data calculations, the significance value indicates the number 0.001 $<0.05$. by addressing that there is a significant increase in the emotional intelligence of children who are treated using sports activity. Sports activity developed at school influences children's emotional intelligence. Emotional intelligence possessed by a student is an important determinant of student success that must be possessed. Emotional intelligence is very important in the success of life, in this case the success that is emphasized is in life at school. Sports activity developed in this study had an impact on increasing children's emotional intelligence.
\end{abstract}

\section{Keywords: sports activity, emotional intelligence}

\section{INTRODUCTION}

The process of increasing emotional intelligence in elementary schools and activities or activities that can affect the increase in emotional intelligence are the basis of this research. In an effort to improve emotional intelligence in elementary school the authors develop it by using physical activity and children's participation in sports. This activity becomes the foundation because physical activity and participation in sports can improve one's emotional and emotional communication. The process of improving communication and emotional intelligence of children is a foundation in the child's social development. Children who have good emotional development will have an impact in communicating the emotions and feelings of the child, this will have an impact in situations that are faced with their affective needs [1]

Awareness of emotions will have an impact in recognizing one's feelings is one of the impacts in developing the emotional integrity of children at the lowest layer and becomes a very important foundation. In addition to having an impact in understanding this development will also have an impact on stress tolerance and empathy, where empathy can encourage the development of one's personal abilities in general. This development must be done by promoting it early and doing it well organized by involving in sports participation. Not only involves sports, parental support is one of the factors in developing students' emotional intelligence. Developing emotional intelligence through motor activities involves constructive relationships between educator-educated, educated-educated, educatedparent, educated-community [2]. With these two factors, how urgent is it to develop students' emotional intelligence. Another thing that has become the basis in developing children's emotional intelligence, is that emotional intelligence can control thoughts and actions related to planning and implementing behavior. Emotional regulation refers to control of sentiments and motives, and cognitive regulation means to control thoughts and actions that are related to planning and execution of behaviors [3]. This will have a positive impact on future life and become a realm to be considered in aspects life.

Demands in the era of globalization demanded that a person has intelligence so that the person does not experience difficulties and challenges. This will make it easier for someone to be able to adapt well. Emotional intelligence possessed by someone is obtained by one's awareness of the existence of objects that are represented by the quality of knowledge to be able to interact with a particular object. The source of emotional state of a person comes from the cognitive aspect where the environment is very influential on feelings. Stress possessed by someone can be reduced or minimized by emotional intelligence, this is if we associate it with the world of sports. The ultimate goal of this control is that one can think when practicing or during a match.

Emotions need to be trained by increasing understanding related to negative and positive emotional impacts. As a result, both negative and positive effects need to be trained, this is useful to improve understanding related to the impact of one's emotions. If someone can manage emotional intelligence well then it will push to become a strength and act that will later be able to determine one's success. The purpose of education in Indonesia can be based on emotional intelligence. The similarity of objectives in the learning process both the interaction between students and thirsty teachers has a similarity so that the goals of the education process can be realized together. It must be understood that how important emotional intelligence is in students.

EQ as the ability to perceive, understand and manage one's own and other's feelings and emotions, to discriminate among them, and use this information to guide one's thinking and action [4]. The purpose of the above opinion is that researchers define EQ as the ability to understand and manage the feelings and emotions of others and themselves, to distinguish between them, and use information to guide one's thoughts and actions. Defined emotional intelligence as the ability to perceive and recognize emotions, to assimilate emotions, to understand the message and meaning of the emotions [5]. Emotional intelligence as the ability to 
understand and recognize emotions, to assimilate emotions, to understand messages and the meaning of emotions. "Emotional intelligence describes the ability, capacity, skill, or self-perceived ability to identify, assess, and manage the emotions of one's self, others, and of groups [6].

Emotional intelligence as the ability and emotional awareness to handle feelings, realize the feelings of others, be able to empathize, entertain, guide, the ability to control impulses, delay gratification, motivate themselves, read other people's social cues and handle the ups and downs of life. Emotional intelligence is regarded as either a trait or an groups [6]. Emotional intelligence is considered as a trait or ability. Based on the understanding of the experts above emotional intelligence can be interpreted as a person's ability to control one's own emotions, others around, manage themselves, assess themselves, accept. Information relating to a relationship can refer to feelings of their own emotions. A relationship and giving reasons to refer to a capacity can be said to be intelligence (intelligence). A study revealed that emotional intelligence is twice as important as intellectual intelligence in Emotional contributing to one's success intelligence is "Research has also found EI to be associated with avariety of individual and social resources, such as resilience,positive self-evaluation, and social support [7].

Participation in organized youth sports has been shown to be apredictor of increased exercise levels in adults. In a 10year longi-tudinal study, researchers found that the age of initiation andduration of participation in organized youth sports was a statisti-cally significant predictor of physical activity in young adulthood [8]. Their findings suggested that elementary-aged children who participated in structured leisure activities experience greater psychosocial development and academic competence than their peers who were not as involved in these types of activities. Clearly, sports participation by youth is an area worth studying, especially as it may develop emotional intelligence and foster success in various aspects of life.

\section{RESARCH METHODS}

The method used in this research is to use a biographical documentation, learning observations, investigative procedures, psychological intelligence tests of emotional intelligence, and experimental methods of sports participation to increase emotional intelligence. The population in this study were elementary school students in Merauke District. While the samples in this study were 80 people taken by purposive sampling. The research design used was one group pretest posttest design. The instruments used in this study use the Life Effectiveness Questionnaire (LEQ).

\section{RESUlT AND DISCUSSION}

Source from the results of data analysis the author did, the authors put forward the results of calculations and conclusions as follows.
TABLE I. TEST FOR EMOTIONAL INTELLIGENCE

\begin{tabular}{|c|c|c|c|c|c|c|c|}
\hline \multicolumn{5}{|c|}{ Paired Differences } & \multirow{3}{*}{$\mathbf{t}$} & \multirow{3}{*}{ df } & \multirow{3}{*}{$\begin{array}{l}\text { Sig. (2 } \\
\text { tailed) }\end{array}$} \\
\hline \multirow[t]{2}{*}{ Mean } & \multirow[t]{2}{*}{$\begin{array}{c}\text { Std. } \\
\text { Deviation }\end{array}$} & \multirow[t]{2}{*}{$\begin{array}{l}\text { Std. Error } \\
\text { Mean }\end{array}$} & \multicolumn{2}{|c|}{$\begin{array}{l}\text { 95\% Confidence } \\
\text { Interval of the } \\
\text { Difference }\end{array}$} & & & \\
\hline & & & Lower & Upper & & & \\
\hline 4.620 & 14.05169 & 1.40517 & 1.83184 & 7.40816 & 3.288 & 79 & 0.001 \\
\hline
\end{tabular}

Based on the calculation of the posttest data in the table above, it is known that the significance value indicates the number $0,000<0.05$. thus, Ho is rejected and Ha is accepted. Increase in emotional intelligence what happens to students aged 9-11 years in Merauke district is the impact of participation in sports. Participation in sports involves various types of sports. In the world of education one of the engagements is in athletics. Athletic sports have an impact on increasing students' emotional intelligence. The study reveals that participating in clinical activities leads to developing emotional abilities among the players [9]. Increased emotional intelligence possessed by male students as well as the ability to have an impact in managing emotions of students. The impact on girls is on the emotional management that students have. Whereas male students are in the emotional dimension and emotional perception. As regards the relationship between emotional intelligence and athletes' gender, statistical association has not been found, although there is a tendency towards slightly higher values in men in general emotional intelligence and its dimensions, emotion perception, self-emotional management and hyperemotional management, whereas in emotion utilization figures are reversed, finding higher scores in women [10].

An increase in emotional intelligence that students have is one of the basics that needs to be developed. Emotional intelligence is obtained because of the awareness of an object that begins with the knowledge of the object and how it interacts with the object [11].This emotional intelligence must be maintained so that it can be applied in daily life and also applied in various sports. With the high emotional intelligence possessed by students it will be easier to control in individual and team sports, because if the emotional intelligence of students is disturbed it will damage in team sports. In achieving the achievements of athletes in a team of emotional intelligence is one of the factors that determine the success of the team. Apart from team sports emotional intelligence also has a role in individual sports. In determining the success of someone both in team sports and individual sports emotional intelligence is the determining factor, but emotional intelligence can also destroy the success of someone in a state of rest, this happens in team sports [12]. Recognizing the feelings of others and the emotions possessed by many people is one of the control of someone's emotional intelligence, this happens because someone can control and refuse the emotional intelligence. 805 emotional intelligence possessed by someone will have an impact on the success of his life in terms of professionalism. Someone who has high emotional intelligence will be able to understand the feelings of others and can process and control emotions [13]

Benchmarks for the success of emotional intelligence possessed by students are related to successful performance in a number of rules applied. Measures of emotional intelligence associate with successful performance in a number of applied setting[14]. Students who have high emotional intelligence do not guarantee success in one's life 
career. With this assumption, students must be equipped with emotional control early on in the school environment or daily life with the participation of sports. Individuals who scored high on intelligence tests were often unsuccessful in their careers and personal lives, unlike those who were good in recognizing, expressing, understanding and regulating emotions [15]. Individuals who can regulate the emotional states are healthier as they can accurately identify and appraise the emotional states, have the abilities to know suitable time and reason to express their feelings, and can affect effectively regulate their mood states [16].

Participation in sports at school using the situated Learning approach will have a tremendous impact on students' emotional intelligence abilities. Sports situation provides the opportunity to test and assess the abilities of emotion, personality [17]. Emotional intelligence possessed by students will be the basis in developing moral students. Morals are the basis of student life both in school and in the field. This moral needs to be cultivated from an early age and maintained so that it becomes a provision in his life. Some research has been conducted to examine the relationship between emotional intelligence and moral development [18]. This approach will have an impact on the students' cognitive abilities. Students who can understand emotional intelligence will be able to reduce students' cognitive intelligence. Weak ability of a person's cognitive ability can be treated when someone can understand good emotions, can control the social environment around them [19].

Students who participate in sports with different intensities will also have different emotional intelligence (EQ). In other words, the more often they are involved in a person's sports participation, it will affect the level of emotional intelligence, because doing physical activity or doing sports does not only affect physical fitness and physical health but also useful for mental health, one of which is emotional intelligence that involves aspects of recognizing one's emotions, managing one's own emotions, motivating yourself, recognizing the emotions of others and building relationships. Physical or bodily activities that intend to provide the development of the individual organically, neuromuscularly, intellectual, and emotional [20].

There are four competencies or abilities possessed by someone in emotional intelligence. The first thing is how one can read the capabilities of other people. Someone can also identify the presence of people who are around him. It also can feel and be able to see other people in doing abilities. Another ability that is possessed is how a person can utilize emotions, the proper management of emotions in the current situation. A good leader is someone who can show his ability to feel, talk, and know what is felt by others [21].

\section{CONCLUSION}

Sports activity at school influences children's emotional intelligence. Sports activity developed at school influences children's emotional intelligence. Emotional intelligence is very important in the success of life, in this case the success that is emphasized is in life in school. Sports activity developed in this study had an impact on increasing children's emotional intelligence. Emotional intelligence of children is influenced by the physical aspects of the child, physical aspects in influencing emotional intelligence include physical movement. Sports activity will have an impact or be related to mental-emotional influence. The physical state of an individual which impacts the emotional intelligence abilities of a person is within the anatomy of the emotional nerve and brain, another part that is used by the body to think is the cortex.

\section{ACKNOWLEDGMENT}

This work was supported by Universitas Musamus, Papua, Indonesia

\section{REFERENCES}

[1] D. Amado-Alonso, B. León-del-Barco, S. Mendo-Lázaro, P. A. Sánchez-Miguel, and D. Iglesias Gallego, "Emotional Intelligence and the Practice of Organized Physical-Sport Activity in Children," Sustainability, vol. 11, no. 6, p. 1615, 2019.

[2] C. Ristea, S. Macovei, and N. Leonte, "The influence of motor activities on the development of emotional intelligence," Eur. Proc. Soc. Behav. Sci., vol. 11, pp. 379-384, 2016.

[3] A. Sadri and H. Janani, "Relationship of emotional intelligence and self-regulation of male elite swimmers," Ann. Appl. Sport Sci., vol. 3, no. 4, pp. 9-18, 2015.

[4] Z. Khan, A. Ali, and N. Ahmad, "Study of emotional maturity among kabaddi and handball players of sports authority of India," Int. J. Phys. Educ. Sport. Heal., vol. 3, no. 5, pp. 454-458, 2016.

[5] U. Gunu and R. O. Oladepo, "Impact of Emotional Intelligence on Employees' Performance and Organizational Commitment: A Case Study of Dangote Flour Mills Workers," Univ. Mauritius Res. J., vol. 20, pp. 1-32, 2014.

[6] O. Serrat, "Understanding and developing emotional intelligence," in Knowledge solutions, Springer, 2017, pp. 329339.

[7] A. Di Fabio and M. E. Kenny, "Promoting well-being: The contribution of emotional intelligence," Front. Psychol., vol. 7, p. $1182,2016$.

[8] S. M. Miller and J. T. Siegel, "Youth sports and physical activity: The relationship between perceptions of childhood sport experience and adult exercise behavior," Psychol. Sport Exerc., vol. 33, pp. 85-92, 2017.

[9] R. P. Malipatil and S. S. Patil, "The Impact Of Sports Participation On Emotional Intelligence Of The Performance Of Athletes And Non-Athletes Of Gulbarga University," Int. Res. J. Phys. Educ. Sport. Sci., vol. 02, no. 02, pp. 1-5, 2015.

[10] M. Castro-Sánchez, R. Chacón-Cuberos, F. Zurita-Ortega, P. Puertas-Molero, M. Sánchez-Zafra, and I. Ramírez-Granizo, "Emotional intelligence and motivation in athletes of different modalities," J. Hum. Sport Exerc., vol. 13, no. 2, pp. 162-177, 2018

[11] P. Riyanto and P. Betaubun, "Effect Of Student Learning Model On Emotional Intelligence," Int. J. Manag., vol. 10, no. 6, 2019.

[12] V. P. Birwatkar, "Emotional intelligence: The invisible phenomenon in sports," Eur. J. Sport. Exerc. Sci., vol. 3, no. 3, pp. 19-31, 2014.

[13] M. Bostani and A. Saiiari, "Comparison emotional intelligence and mental health between athletic and non-athletic students," Procedia-Social Behav. Sci., vol. 30, pp. 2259-2263, 2011.

[14] S. Saadati, R. Nikbakhsh, and A. Afarinesh, "The relationship between emotional intelligence and athlete burnout," Bull. Environ. Pharmacol. Life Sci., vol. 18, no. 21, p. 179, 2014.

[15] T. S. Batinić, V. Švaić, and J. Babić, "Differences in emotional competence between individual and team sports athletes," in 7th International Scientific Conference on Kinesiology-Fundamental and Applied Kinesiology-Step Forwards, 2014.

[16] R. O. Dev and A. R. A. Rahman, "Influence of emotional intelligence as the mediator between physical activity and mental health (distress) among malaysian university students," Int. EJournal Adv. Soc. Sci., vol. 2, no. 5, pp. 492-500, 2016.

[17] S. S. Patil and R. P. Malipatil, "THE Influence Of Sports Participation On Socio-Psychological Variables Of Sportsperson," Eur. J. Phys. Educ. Sport Sci., 2016.

[18] S. Can, "Can emotionally intelligent volleyball players be more prone to sportspersonship?," J. Educ. Train. Stud., vol. 4, no. 7, pp. 54-60, 2016.

[19] B. B. Gail, "The effects of youth sports participation on 
emotional intelligence in middle school students." San Diego State University, 2012.

[20] A. M. Fadlih and P. Riyanto, "Minat dan Motivasi Peserta Didik Penyandang Disabilitas Ketunarunguan terhadap Mata Pelajaran Pendidikan Jasmani Kesehatan dan Olahraga," Musamus J. Phys.
Educ. Sport, vol. 2, no. 01, pp. 68-76, 2019

[21] B. S. Bal, K. Singh, M. Sood, and S. Kumar, "Emotional intelligence and sporting performance: A comparison between open-and closed-skill athletes," J. Phys. Educ. Sport. Manag., vol. 2, no. 5, pp. 48-52, 2011 